\title{
SPORT AS METAPHOR FOR SOCIAL DYNAMICS IN THE HISTORY OF POPULAR CULTURE
}

\begin{abstract}
Robert M. Levine ${ }^{1}$
RESUMO: O esporte tem sido um dos temas marginais da historiografia, contudo sua penetraş̃o social 6 imensa. A presença do esporte na vida cotidiana tem sido, recentemente, revelada como meio de análise da estrutura social. Com o presente texto pretende-se um questionamento sobre alternativas de estudo do esporte como metáfora da dinâmica social.
\end{abstract}

PALAVRAS-CHAVE: Esporte, futebol, cultura popular, estrutura social, cotidiano

"Every boy likes baseball. And if he doesn't, he's not a boy." (novelist Zane Grey, 1910)

The past decade has seen a significant change in the ways historians and social scientists have approached the subject of sports in society. The quality of published data has improved markedly; more research is being done, and - even more importantly - the questions that researchers are asking are becoming more sophisticated and far-reaching. The purpose of this essay will be to explore some of the new ideas and hypotheses being debated by specialists in sport history. It will also speculate on aspects on these topics which might prove applicable for historians of Brazilian society. After all, sport is a metaphor for social dynamics. Sport is accessible. It touches nearly everyone in society, and it is more egalitarian than most other social institutions. It offers a mirror to see ourselves through informed self-examination ${ }^{2}$.

Research in the United States and Canada since 1980 has focused not so much on sports themselves as on the symbolic implications of athletes as well as the larger issue of sport-related public behavior. Much of the research

1 University of Miami. Coml Gables, FL.

2 An important source combining theory with a practical agenda on the issue of sport and society is Harry Edwards, The Sociology of Sport. Hoinewood, Illinois: The Dorsey Press, 1973. 
LEVINE, Robert M.. Sport as metaphor for social dynamics in the history of popular culture.

on these questions has been conducted by contributors to the Arena Review, published since 1976 at the University of Nevada, Las Vegas, and by members of the North American Society for the Sociology of Sport. Other important work is being done by the North American Society of Sport History, the Institut fur Portgeschichte in Koln, and the Iestnevelési Foiskola, Todományos Kozlemények in Budapest ${ }^{3}$.

What are some of the questions that these watchers of popular culture have asked during the past ten years?

1. What is the impact of public acclaim on athletes and their self-esteem and performance? Does athletic success prepare individuals for life after cheering and adulation stops?

Sociologists of popular culture have asserted that the development of one's self-esteem takes place in particular social contexts, and the higher the athlete's status, the higher the self-esteem ${ }^{4}$. What happens when an athlete's status declines as his performances peak and he declines as a productive athlete? What happens when an athlete is demoted to part-time status, or to lower-level competition, or leaves the sport entirely? Since self-esteem is reinforced (and largely depends upon) positive reinforcement from peers, it can have a negative effect when the attentions of crowds, sportswritters, commentators, and teammates shift do other, more productive athletes. It would be very instructive to study career patterns of futebol players in their downward trajectory, and not only the Friedenreiches, Pelés, and Garrinchas, but players of lower ability levels who climb out of a lower-class environment to star briefly for a professional team, then quickly fall into obscurity after their playing days end. What do these players do after they stop playing? What happens to their economic condition, to their social relationships, to their families?

Conversely, do athletes who leave sport suffer not only downward mobility but a reduction in self-esteem? In the United States, where involvement in sport as a percentage of each age cohort is far higher than anywhere else in the world because of the unique premium placed on team participation in all of the nation's secondary schools as well as in $95 \%$ of its 3,500 large universities, research on non-participants, as well as on those who terminate

3 I thank Prof. Andrew Handler for this information.

4 Tim Jurkovac, "Big-Shot' Collegiate Athletes: Effects of High Status Roles and Ritualistic Objects on their Self-Esteem and Performance," Arena Review, 1;2 (November 1987), 19-27. 
participation because of injury or disaffection, ressearch has found that the impact on the individual varies in relation to social class. Only one tenth of one percent of all participants in organized sports in the United States ever earn professional contracts or are able to make a career of sports.

Youths from middle-class and upper-middle class backgrounds seem to understand this, and therefore tend to transfer their self-esteem and competitiveness from sports to other outlets. Working-class youths, however, and especially blacks and hispanics, who tend to romanticize sports as a "magic carpet" out of low status or poverty, often suffer disorientation or psychological deppression when they find, at age 18 or 19 , that although they have been superb athletes in one sport ou another, they are not good enough to play professionally. These young men, who depend on sports sources to define success and masculinity, have their hopes dashed by reality they did not want

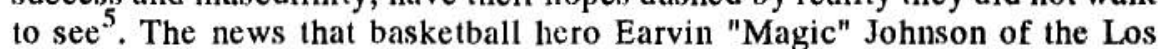
Angeles Lakers in November 1991 has the AIDS virus and at the peak of his career had abruptly to retire had a stunning impact on children and youths in the black population: it provoked grief, somberness, and an unprecedented amount of self-examination, in most cases for the first time in the lives of these young people ${ }^{6}$. For young blacks and hispanics, the news about Johnson has had exactly the same impact as the news in 1963 among the population at large that President John F. Kennedy had been shot.

\section{Do sports foster self-discipline among athletes?}

A case study for the affirmative may be seen in the career of Fidel Castro. As a student at Belén School in Havana, run by the Jesuits, Castro was a noted athlete. As a freshman he "publicly challenged the president of the Student's Union to a boxing match over a point of order in a debate." ${ }^{7}$ Hugh Thomas tells that Fidel rode a bicycle at full speed into a brick wall to prove he had the will-power. He played baseball, basketball, and was a 400 -meter runner for his school. Once, after an attack on a Cuban naval vessel, he swam nine miles to shore against a strong current to avoid captuging Meaning of Male Identity in the Lifecourse of the Athlete. University of Catifornia, Bekerley, 1985.

6 See, for example, Michael Specter, "When AIDS Taps a Hero, his 'Children' Feel Pain, "New York Times, November 9, 1991, p.1.

7 John Sugden, Alan Tomlinson and Eamon McCartan, "The Making and Remaking of While Lightning in Cuba: Politics, Sport and Physical Education 30 Years After the Revolution", Arena Review, 14:1 (1990), 107. 
LEVINE, Robert M.. Sport as metnphor for social dynainics in the history of popular culture.

$\mathrm{re}^{8}$. Three British specialists who have studies Castro's life have concluded that there is little doubt that his physical stature, athleticism, and discipline helped to sustain him as a guerrilla under difficult conditions in the Sierra mountains during the $1950 \mathrm{~s}$.

Another political activist, the American Ron Kovic, an enthusiastic career soldier and Vietnam veteran who after his return from Southeast Asia as a quadriplegic became an ardent leader of the anti-war movement, confirms this argument. In his angry war autobiography made into a movie, Born of the Fourth of July, Kovic outlines his personal progression from playing with war toys as a child, his weightlifting and playing football as a young man, and his attempts to impress girls with his muscular abilities with his decision to join the Marine Corps and fight in Vietnam. Boy athletes have historically had a much higher rate of volunteering for the armed forces, where athletic prowess was esteemed not only during peacetime but during war itself, as in the case of World War $\mathrm{II}^{10}$.

Studies of career patterns of men who have excelled in sports as then continued in successful careers in business, government, and other, mostly entrepreneurial activities, tend to support the hypothesis that Fidel Castro's emergence as a charismatic leader was a result of his drive and explosive inner stamina - not something he acquired through sports, but an personality trait he used to win success not only in sport but as a political militant. In the United States, the number of former athletes who have succeeded in politics is impressive if not worrisome, including George Bush, who played first base on Yale's baseball team; Gerald Ford, an All-American football lineman at the University of Michigan; Tom Mcmillan and Bill Bradley, former Rhodes scholars and professional basketball players, and now United States congressmen. Whether self-discipline and other career-aiding attributes can be attributed to athleticism, remains to be seen. Detailed studies of athletes, especially from impoverished backgrounds, in comparison to peers from the same origins who did not become athletes, would seem to provide a fruitful opportunity for sports research. It would also be very valuable to have a study of players and cartolas who have entered politics. I am not simply advocating biographies of such persons as Zico, Barnard Rajazman, or Marcelo Braga as much as I am calling for studies of the "transference principle", a phenome-

8 Hugh Thomas, Cuba, the Pursuit of Freedom. New York, 1971, cited by Sugden et.al.

9 John Sugden, Alan Tomlinson and Eamon McCartan, "The Making and Remaking of While Lightning in Cuba," 107.

10 D. Sabo, p. 14. 
non through which fame in one area of society "transfers" to other, non-related areas, aided and abetted in the late twentieth century by the power of the mass media.

\section{How do sports influence gender roles in society?}

A clue may be found in the research of $\mathrm{N}$. Chodorow that founds that women's social orientation in personal, but men's is positional. In other words, girls learn to anticipate and satisfy the needs of others, whereas boys learn to separate themselves from others and stand independently ${ }^{11}$. For male athletes, moreover, the tendency to separate themselves psychologically, and "to isolate competitive outcome from the well-being of other", is a psychological derivate of hierarchy, according to another researcher, the foremost cause of alienation ${ }^{12}$.

Two premisses govern the topic of gender and sport. First, in the words of Don Sabo, that "a main function of traditional sport is to teach (athletes) conformity to patriarchal values." ${ }^{13}$ Sport, the argument goes, as a major vehicle for male socialization shapes men's individual and collective behavior. The second premise is that patriarchy oppresses not only women but men. It emphasizes male dominance. Patriarchy exaggerates gender differences. Socialization for manhood, after all, often revolves around aggression ${ }^{14}$. Team membership and participation pits men against one another: members of one's own team against whom players compete for more favorable roles, and against opponents.

Sex roles among athletes, the explanation continues, are organized to fit broader institutional patterns of the intermale dominance hierarchy. The coach (técnico) represents a commanding authority figure, whose favorable word can bestow status and more playing time, and whose displeasure brings swift retribution. The coach, of course, is a "man among men, an occupant of a culturally-defined male role, and a resident of the intermale hierarchy." 15 Female teams, by contrast, are not nearly as popular as male teams, and are

11 N. Chodorow, The Reproduction of Mothering: Psychoanalysis and the Sociology of Gender, Berkeley: University of California, 1976.

12 Don Sabo, "Sport, Patriarchy, and Male Identity: New Questions about Men and Sport," Arena Review, 9:2 (November 1986), p.8; F.C. Thayer, An End to Hieranchy and Competition: Admi. nistration in the Past-Affuent World, New York; New Viewpoints, 1981, cited by Sabo.

13 D. Sabo, p. 1.

14 Sabo, pp. 1-2, 18.

15 D. Sabo, p.2. 
often identified in the public mind, accurately or not, with female homosexuality ${ }^{16}$.

Sports conditions athletes to conform to patriarchal values by rewarding them for thinking hierarchically, and to value positively (and not reject) status differences. By virtue of his membership in the male collectivity and because of the notoriety publicity brings, talented athletes, from the first moment their superior athletic talent becomes evident, are bestowed with an inordinate jump in status. They now stand not only over other, non-athletically-talented males, but over all women, who except in the rarest of circumstances, cannot come close to matching the male athlete's prowess ${ }^{17}$.

Since males, not females, have been socialized for competitiveness, sport analysts argue that social adulation of athletics bolsters male chauvinism. In modern life, where competition is considered a legitimate path to economic success, those who manage to acquire status and power outside the home, bring it to the family relationship. Since one of the only ways for economically disadvantaged individuals to attain this status and power in society is through sport, feminists (and male social psychologists) contend that this monopoly of providership roles has exploited women because they remain economically dependent on men ${ }^{18}$.

\section{Does sport encourage participant violence?}

Normative violence occurs within games and matches when players attack opponents within the permited boundaries of established rules; illegitimate violence occurs when players deliberately seek to harm targeted opponents outside of the rules of the sport. Although subject to penalty when the play steps beyond the boundary of tolerated violence-a frontier which varies from match to match depending on the importance of the contest and the attitudes of the referees. In United States basketball at the university level, for example, it is a commonly believed, for example, that referees will be more lenient in calling personal fouls in games of great importance that are regionally or nationally televised, except when the fouls are flagrant, or when an atmosphere anticipating player violence is expressed publicly before the games is played. In these, cases, referee are likely to call more fouls than

16 I am indebted to Quelia Quaresma for this observation.

17 See D. Sabo, Pp. 3-4.

18 Sabo, p. 5 See also M. L. Anderson, Thinking About Women: Sociological and Feminist Perspectives, New York: Macmillan, 1983. 
usual, not fewer, in an effort to demonstrate their control. Although approved by coaches, other players, and spectators, this kind of deliberate, aggressive violence can lead to injury. The distinction between legitimate and illegitimate violence is usually blurred, though, and as a result it remains a frequently used tactic because even the anticipation of rough play can effectively intimidate opponents and give the aggressive team an edge ${ }^{19}$. Obviously, sports mirror violence or violent tendencies prevalent in the larger society. In addition, economic incentives and sports journalism encourages, in certain cases, athletes to cultivate the image of an aggressive thug, especially athletes who are physically strong but who otherwise are not as agile (or game-intelligent) as their peers.

Most observers have deplored the use of sport-specific violence although they acknowledge that it has become universally ingrained in sports behavior. Psychologists, in fact, have concluded that adults respond with increased pugnacity after observing a violent action ${ }^{20}$. Jay Coakley, in an imaginative comparison of prisons with player training camps, argues that both settings engender violence. Both settings, he argues, deprive autonomy, which threatens adulthood; they deprive security, which threatens physycal well-being and they deprive heterosexual relationships, a threat to masculinity. Training camps of course are not prisons, but the subjective meanings of the deprivations experienced under incarceration to the psychologist parallel the meanings of the deprivations experienced by the training-camp athlete. Players responding collectively to these threats, the argument goes, develop a social system in which violence becomes accepted as normative behavior to preserve self-esteem and to protect one's own well-being ${ }^{21}$. A complementary study, by Sabo and Runfola, concludes that many port subcultures are vehicles of the "machismo" syndrome, and therefore identify aggression and violence with manhood, especially within the isolated world of serious sports training ${ }^{22}$.

Testing these theories has yielded engaging results. Psychologists emphatically assert that belligerent behavior is acquired, not generically inherited, despite the persistence unscientific myths to the contrary ${ }^{23}$. Ont

19 John Sclıneider and D. Stanley Eitzen, "The Structure os Sport and Participant Violence," Arena Review, 7:3 (Nov. 1983), 3.

20 L. Berkowitz, "The Effects of Observing Violence," Scientific American, 210 ( $1 \% 64$ ), 35-42.

21 Jay J. Coakley, "The Sociological Perspective: Alternative Causations of Violence in Sport," Arena Review, 5 (February 1981), 44-57; Schneider and Eitzen, 5.

22 Don Sabo and R. Runfola, eds. Jock: Sports and Male Identity. Englewood Cliffs, NJ: PrenticeHall, 1980. 
LEVINE, Robert M.. Sport as metaphor for social dynamics in the history of popular culture.

set of investigators found that the lower the scoring in the contest, the greater the potential for illegitimate violence. The reason for this is that in a low-scoring contest, tension and frustration levels build up on the playing field, generated by the fear of making a crucial error which will bring on defeat. There is also a valid inverse correlation between the use of normative body contact and illegitimate violence: as the amount of legitimate body contact increases, there are fewer acts of non-sanctioned violence ${ }^{24}$.

One school of thought holds that the use of normative violence (and possibly even illegitimate) violence in sports is cathartic: that when violence occurs on the playing field, and is vicariously absorbed into the spectators' excitement, the result can be beneficial because the violence is left behind on the field when the match ends. Belligerence, even when it represents learned behavior, is seen as a component of motivation. Consider the point made by A. Storr in the book Human Aggression:

One difficulty is that there is no clear dividing line between those forms of aggression which we all deplore an those which we must not disown if we are to survive. When a child rebels against authority he is being agressive... The desire for power has, in extreme form, disastrous aspects which we all acknowledge; but in the drive to conquer difficulties or to gain mastery over the esternal world underlies the greatest human achivements ${ }^{25}$. of society?

5. Can conflict theory help understand and analyze sport as an aspect

What D. Stanley Eitzen has called the "conflict perspective", the study of social structures as a totality, permits us to see sport in a way different from funcionalist analysis ${ }^{26}$. The conflict paradigm holds that conflict is endemic in social organizations, since power and resources are never distributed equally and because those in power use that power to retain it. Analysis of any institution under conflict theory, then, requires an examination of the political economy and from the premise that resources dictate power.

23 See Jay J. Coakley, Sport and Society: Issues and Controversies, St. Louis: C. V. Mosely, 1978.

24 Schneider and Eitzen, 6-7.

25 A Storr, Human Aggression. New York: Athenaeum, 1968, 2-3, cited by Schneider and Eitzen, p. 4.

26 D. Stanley Eitzen, "Conflict Theory and the Sociology of Sport," Arena Review, 8:3 (November 1984), 46. 
Examining sports through this lens, Eitzen avers, permits the researcher to direct their attentions not to the mechanisms that reduce conflict (for example, relations between of different racial backgrounds on sports teams) but to the social barriers that habe hampered integration and upward mobility historically. Eitzen's own research has concluded that the premise that contemporary sport in America is an island free of racism is utterly wrong ${ }^{27}$. Some of his work has been on the subject of "stacking", an unwritten system whereby American blacks have been relegated to specific team positions requiring sheer physical abilities rather than, say, leadership qualities and cognitive skills ${ }^{28}$. Other research using conflict theory has focused on the dynamics of interaction within the sports establishment, among the North American equivalents of cartolas ${ }^{29}$.

\section{Conclusion:}

It is instructive to note that even social scientists, who should know better, fall victim to the trap of predetermining their conclusions by framing their research questions in a flawed manner. Functionalists, Don Sabo reminds us, talked about "cultural norms", while Marxists argued about "capitalist ideologies" ${ }^{30}$. Popular culture historians investigating sport have tested hypotheses designed to find out whether men's athletic careers foster desirable personality traits and increased occupational achievement. Such research is suspect because it in based on the implicit assumption that competitive success and the transfer of aggressiveness from the playing field to the corporate suite are desirable goals. The implications, in short, of the dominant male status hierarchy and the social system have traditionally been left unchallenged $^{31}$. This unfilled need constitutes the agenda for future work in the field.

Where does this leave us in terms of prospects for the study of Brazilian sport? One obvious distinction which calls for further study is the

27 Eitzen, p. 49.

28 Bitzen, 49, citing Eitzen and In Tessendorf, "Racial Segregation by Playing Positions in Sports: The Special Case of Basketball," Review of Sport and Leisure, 3 (Fall 1978), 109-28.

29 It would be interesting to have a comparative study of such Brazilian sports fiures as Corinthians' Vicente Mateus and Americans like George Sieinbrenner or Paul Brown.

30 D. Sabo, pp. 24-25, citing B. McPherson, "Sport in the Educational Milieu," Phi Beta Kappa, 6 (1980), 605-06. 
LEVINE, Robert M.. Sport as metnphor for social dynamics in the history of popular culture.

cultural and social significance of the rise of sports other than futebol in the national minds. For decades, the average Brazilian breathed futebol as naturally as the air, yet except for a few was only merginally aware of achievements of Brazilians in other sports. One wonders how many Brazilians not only knew about Maria Ester Bueno during the 1950s as a tennis champion but understood (or cared) anything about her sport.

This, of course, has changed, but to what degree? Network television, of course, has spurred greater recognition. The preeminence of Emerson Fittipaldi and Airton Senna in automobile racing has brought this activity, typically a plaything of the rich, to national attention. International victories is vachting and sailing offer another obvious example, altought presumably far fewer Brazilians are aware of these. Similar examples to the automobile racing case may be found in the cases of Ayrton Senna da Silva, Emerson Fittipaldi, Rubens Barrichello; in basketball Oscar Smith, Hortência Oliva in track-and-field, and in tennis Jaime Oncins, Luis Mattar.

One area which would seen to be especially fruitful for Brazilian historians of popular culture to investigate would be the theme of race. In the United States in the 1990s, serious questions are being raised about blacks in professional and amateur sports, attempting to separate myth and common belief from reality, 44 years after blacks broke the color line and were integrated into baseball, football, and other sports. Despite dramatic increases in player's salaries-the average yearly salary for a rookie (first-year) basketball player in the National Basketball Association, which is $70 \%$ black, exceeds one million dollars. Yet a detailed survey commissioned by Sports Illustrated magazine in 1991 showed that $61 \%$ of black athletes maintained that their salary and contract terms were less favorable than those for whites; $60 \%$ believed that they were not as well treated by management as whites are; $73 \%$ believed that they were less likely to be offered contracts to advertise or endorse products; $69 \%$ felt that whites got preferential treatment in filling key positions os the field or court, and $67 \%$ believed that management in their sport was not doing enough to hire blacks as coaches and other positions of field management or as executives after retirement from active competition $^{32}$. Empirical research has confirmed some of these perceptions. A recent exhaustive analysis of the performance of white, black, and hispanic major league baseball players between 1955 and 1984 supports the marginality theses: that darker-complexioned players are the first to be cut from temas 
when their performande declines. They are less likely to be kept on a substitutes or utility players. There is, in all, "unequal opportunity for equal ability ${ }^{\text {33. }}$.

Dozens of issues related to sport and Brazilian society merit study beyond what already has been done ${ }^{34}$. A detailed study os the career trajectories of all professional futebol players since the 1930 s could easily be done easing the records of the CBD, and a computer, complemented by oral history. This could yeld invaluable information about upward and downward mobility, about the racial aspects of sports fame, and about self-esteem and mental health ${ }^{35}$. Is there any longer a stigma attached to women following sports as enthusiastically as men? What about spactator behavior, the impact of legal (and illegal) betting on the outcomes of matches? What about the psychological impact of a win (or a loss) in World Cup competition? Is the historical national passion for futebol diminishing? If so, why? What are the substitutes, if any? How does diet and nutrition affect the emergence of future athletic stars from the lower classes? Do Brazilians feel more comfortable with marriages between whites and non-whites if the male is a famous athlete? If racial prejudice is not present, then why are these so few marriages between white men and dark-skinned women? These and a myriad of other questions remain to be answered, not only about the history of sport in Brazil but about larger (and, in the last analysis, more meaningfull) issues growing out of the impact of sport on society.

ABSTRACT: Sport has been one of the marginal topics in historiography; however, its social penetration is imense. The presence of sport in daily life has been, recently, revealed as a means of analysis of the social structure. The intention of the present text is a questioning about alternatives to the study of sports as a metaphor to the social dynamism.

KEY-WORDS: Sports, soccer, popular culture, social structure, daily

33 William M. Leonard, Jon Pie And Connie Rice, "Performance Characteristics of White, Black, and Hispanic Major League Baseball Players, 1955-1984," Journal of Sport and Social Issues, 12:1 (1988), $31-43$.

34 See Joel Rufino dos Santos, "Na CBD até o papagaio bate continência," In: Encontros com a CivilizaçäoBrasileira, 5 (Nov. 1978); Matthew G. Shirts, "Literatura futebolística: uma periodizaçâo," In: José Carlos Sebe Bom Meihy \& José Sebastiâo Witter, orgs. Furebol e cultura: coletâneo de estudos. Săo Paulo: IMESP/DAESP, 1982, pp. 45-69.

35 See R. Collins, Sociological Insight: An Introduction to Non-Obvious Sociology. New York: Oxford University Press, 1982. 